\title{
A Survey of Awareness and Perception of Digital Library Services in Nigeria
}

\author{
K. Towolawi Oluwakemi, PhD \\ University Library, Bells University of Technology, \\ PMB 1015, Ota Ogun State. Nigeria
}

\begin{abstract}
This research study examined the awareness and perception of School Librarians (SLs) who are also referred to as School Library Media Specialists (SLMS) towards Digital Library Services (DLS) in Nigeria. This research is an avenue for gaining deeper understanding of the needs evolving from the professional cum operational use of digital libraries by information professionals all over the world. A Survey method was used for the study. A sample size of ninety professionally trained school librarians/SLMS; constituting $83.3 \%$ of the one hundred and eight participants that attended the $26^{\text {th }}$ Annual General Meeting (AGM) and National Conference of the Nigerian School Library Association (NSLA) were selected through random sampling technique. The Critical Appraisal of Digital Library Awareness and Perception Questionnaires (CADLAPQ) which was an adapted Questionnaire was used to collect data. The ensuing data from the field exercise were analysed using descriptive statistical tools such as tables, charts, graphs, percentages and frequency distribution. The results showed that school librarians have very low perception and awareness on the existence of digital library. Also, their perceptions were adjudged to be quite different from what the digital library services really entails and or is really all about. The study, therefore, recommended, that, school libraries in Nigeria should endeavor to include the teaching and learning of digital library services into the school library syllabi. School Library trainings should also include the inculcation of the right type of skills, perception, and awareness in addition to covering the cognitive domain of the utilization of information resources in digitized formats to offer quality and timely services to school library clienteles..
\end{abstract}

\section{General Terms}

Digital library Survey, School Library Media Specialist, Digital library Perceptions, Digital library Awareness. Digital Library Services

\section{Keywords}

Digital library Survey, School Library Media Specialist, Digital library Perceptions, Digital library Awareness. Digital Library Services, Nigeria.

\section{INTRODUCTION}

The library and the professionally trained librarians have been very useful with the storage and retrieval of relevant educational research and teaching information for application (Onuka and Towolawi, 2012). Thus, in their traditional print-based environment, libraries and of course professionally trained librarians have always been guided by the objective of linking users with timely and relevant information resources. In the traditional setting of the library, library works are done mostly without the use of information technology and time is usually consumed depending on the nature of search and query of patrons. However, the scenario has changed with the use and application of information and communication technology (ICT) especially in libraries (Bagudu and Sadiq, 2013). Omekwu, (2006) also posit that the digital technology of the $21^{\text {st }}$ century has radically redefined information product; thereby creating a shift in paradigm in information handling and dissemination. These changes, he pointed out, have been sufficiently unprecedented and have attracted enduring shift to digital frontiers. The paradigm shift as he noted is dominant, diverse and dynamic. Consequently, information and knowledge practitioner risk sticking to traditional practices. There is the need to accept novel methodologies and practices to provide better and broader latitude of information system transactions and dissemination in the digital economy era. Thus, to Omekwu, the phrase "anytime" and "anywhere " captures the anticipation, the passion and requirements of the world hunger and thirst for access to knowledge.

Corroborating the above, Kimani, Panizzi, Catarci and Antona (2005), stated that the socio-technical culture and technological advances of man have led to a rather overwhelming rate of creation and dissemination of digital information. Thus, technology has changed how libraries work but not why libraries exist. The most profound of all these technological developments is the connection of computer to computer in unbroken chain around the world. The above of course, have altered totally the concept of the library in the $21^{\text {st }}$ century and as more and more information sources become available online, libraries world over are introducing digital service for their clientele. As reiterated by Bagudu and Sadiq, (2013), the aim of digital library services is to broaden the range of information resources available and to add value to library content by making them accessible through digital means. These content can thus be made accessible to students and researchers anytime and anywhere. Thus, libraries without walls, are actually libraries with new walls which are technologically bounded, legally restricted and organizationally confined. Researchers world over, have reported that technology has enabled the digitization of documents, text, sounds and images in such ways that information, which may not necessarily be knowledge is made available virtually anywhere and anytime via internet connected devices. Terry and Cleveland, (1997) corroborated the aforementioned by stating that technology have not substantially alter "why librarians" for connecting people with information but, it has changed "how" librarians connect people to information.

Therefore, for librarians and information professionals to remain relevant in the $21^{\text {st }}$ century, a clear and an effective digital library awareness and perception survey becomes increasingly important. Bagudu and Sadiq (2013), 
corroborating and quoting Chowdhury and Margariti (2004), further pointed out that the introduction and development of the Internet and its associated Web technologies in the past decade have significantly influenced both the way libraries provide information services to their users and the way users choose to access information. Moreover, all types of libraries are now striving to meet the needs of their patrons through the provision of digital library collection in developed nations of the world by improving their services and enhancing their resources. Perhaps, a thriving means of enhancing digital library services and resources provision is by ensuring that the providers' and users' are really aware of the existence of such in order to promote efficiency and effectiveness of services in libraries.

\section{LITERATURE REVIEW}

Digital library is transforming education and research by providing organized access to high quality resources and tools that support innovations in teaching, learning and research at all levels (Ubogu, 2006). The DL evolution, prospects and problems have been researched and written about, ever since they were first developed (Inyiama and Asogwa, 2012; Chu and Krichel, 2012). For instance, Borgman, (1997) explained what digital Libraries are, Kuny and Cleveland (1997) considered the Myth and challenges of a DL and Barry (1996) illustrated DL as a new initiative with worldwide implication, while Harley, (2007) surveyed the Use and Users of Digital Resources. Students' readiness to use was examined by Abdullahi and Zainab, (2007), Users Perception of DL (Tammaro, 2008) and Bodomo, (2003) reiterated that some students still read books in the $21^{\text {st }}$ century and Kanyengo, (2006) particularly explained how to manage the digital resources in Africa. In addition, Adams and Blandford (2002) considered the unseen and unacceptable faces of Dl. While Jeng, (2006) explained usability in the context of the Dl, with Speir, (2006) considering resource sharing in the digital age. Many more papers have been published with regard to trends of DL services in Africa (Ubogu, 2006), adoption of digital library software, standards and related topics, the digital libraries biography (e.g., Jose, (2007); Greenstein and Thorin, 2003). Furthermore, the evaluation of digital libraries, which is a subject of interest to the information science community also received proper attention as well. For example, Fuhr, et.al discussed evaluation of digital library and suggested a framework for evaluation using the systems approach (Fuhr, et al 2007]. Xie described user's evaluation of DL, their uses, criteria and assessment (Xie, 2007). One also sometimes hears the internet been characterized as the world's library for the digital age.

The above description however, does not stand up under casual examination and it appears no consensus has been reached about the definition of digital libraries. Nevertheless, the internet and particularly its collection of multimedia resources known as the World Wide Web was not designed to support organized publication and retrieval of information as the traditional libraries. However, the digital library concept requires that librarians be information architects in order to build effective information service in the digital millennium (Omekwu, 2006). As noted by Barry, (1996) we are witnessing an explosion of digital information, some of it in unstructured repositories, while others are still in primitive stages. As he noted, the trend is certain to accelerate as the National
Information Infrastructure (NII) and Global Information Infrastructure (GII) become a reality. In addition, as reported in developed nations, several digital library projects are in progress, with the goal of developing the enabling technologies for creating a single, integrated and "universal" library which will be composed of the largest numbers of individual heterogeneous repositories. These, Barry noted includes materials in personal information collections, collections in conventional libraries, and large data collections shared by scientists, engineers and other researchers. However, there exist many boundaries within which the digital library services is evolving. The digital library enables its users to leverage information by bridging the gap between the context of information and the application of knowledge. And a key consideration in bridging the gap is to delineate between the digital collection and the true digital library. Accordingly, Cherry \& Duff (2002) opined that the gathering of information constitutes a digital collection, while the provision of accessible usability via systems for searching, browsing, accumulation, synthesis and correlation bring such collections alive in converting such information to knowledge. Thus, the professional Librarian is saddled with the responsibility to transform information to knowledge and not technology.

\subsection{Concept of a Digital Library}

There are multifarious definitions of the term digital libraries as there are researchers. However the definitions were identified by Xie, (2007) and the United State Association of Research Libraries (USARC, 1995) to have common elements of not being a single entity, being a library that requires technology to link its many resources and the linkages between the many digital libraries and information services must be transparent to the end users; while universal access to the libraries and its information services should be a goal, the digital library collections are not expected to be limited to document surrogates but must extend to digital artifacts that cannot be represented or distributed in printed formats or equivalent.

The common elements of a digital library definition identified by the Association of Research Libraries (1995) are more acceptable to researchers of digital libraries: the digital library is not a single entity; it requires technology to link many resources and the linkages between the libraries and information services are transparent to the end users, with universal access and information services as a goal. In addition, its collections are not limited to document surrogates, they extend to digital artifacts that cannot be represented or distributed in printed formats.

Thus, A digital library is a particular kind of information system which consists of a set of components, typically a collection (or collections) of computer system offering diverse services on a technical infrastructure, people, and the environment or usage (Fuhr Norbert et.al, 2007). Cherry \& Duff (2002) corroborating Borgman, et. al. (2003, 2000, and 1999) defined digital library (DL) as a set of electronic resources and associated technical capabilities for creating, searching, and using information. In this sense DL are an extension and enhancement of information storage and retrieval systems that manipulate digital data in any medium (text, images, and sounds, static or dynamic images) and exist in distributed networks. Accordingly, Agosti, (2011) quoted the Digital Library Federation (DLF, 1998) to define digital libraries as 
organizations that provide the resources, including the specialized staff, to select, structure, offer intellectual access to, interpret, distribute, preserve the integrity of, and ensure the persistence over time of collections of digital works so that they are readily and economically available for use by a defined community or set of communities. While, Vijayakumar \& Vijayakumar (2002) in his own definition defined digital libraries as organizations that provide the resources, including the specialized staff, to select, structure, offer intellectual access to, interpret, distribute, preserve the integrity of, and ensure the persistence over time of collections digital works so that they are readily and economically available for use by a defined community or set of communities. To him, Digital Libraries offer such benefits as equitable access, reduced barriers of distance, timeliness, shared resources and content delivery.

Conclusively, from the aforementioned definition, digital libraries are set of library activities and services which facilitate by electronic means the processing, transmission and display of information. It could also denote the technology librarians use to gather information, share, distribute and communicate its users through computers and computer networks. In order words, DL comprises of information sources, services and personnel's that are electronically administered and legally controlled. That is, digital libraries are technologically supported entities linking information sources, services and users with universal access in different formats. Furthermore, the digital library is an electronic depository and laboratory of information. In order to corroborate what the DL denotes, Kanyengo (2006) in Noruzi (2004) revised the Raganantan's five laws of Librarianship in the context of what they would mean for information provision in today's digital environment by stating them as:

"Web resources are for use

Every user his or her web resources

Every web resource its user

Save the time of the users

The web resource is a growing organism"

Web resources are for use only in digital environments, thus a digital library can be likened to a library with web resources and services for its users. Thus, the digital library is any set of digital resources and services system that create, store, analyze, organize, retrieve and disseminate information. Conclusively, A digital library is a repository of electronic resources and or a set of retrievatory (information retrieval systems) that accept electronic information as input, process such with the aid of predefined search and data mining skills, and with the aim to produces information outputs for knowledge creation. However, a digital library must allow its users to assemble essential slices of information needed (customization), while delivering the information at their points of need i.e. (anywhere), as deem (convenience), using standard tools and systems (accessibility) to connect similar interest (community) with reference to user behavior.

\subsection{Evolution of Digital Library in Nigeria}

The launching of the World Digital library in April, 2009 marked the beginning of digital library services according to Bagudu and Sadiq (2013). In Africa and Nigeria in particular, digital libraries was reported by Abubakar, (2010) to still be at infancy level, while in other parts of the world the development of such libraries has reached advanced stage. The state of library and information environment in Nigeria as noted by Abubakar was not very encouraging. The reasons were adduced to the existence of widespread poverty, high illiteracy rate, poor funding of education and libraries, lack of infrastructures, as well as large scale corruption that has eating deep into the fabrics of the Nigerian society. These and many more factors tend to create a very hostile and unpleasant information environment while the priority of most Nigerians is on survival. Inyiama and Asogwa (2011) posit that there are three indicators which determine the myth or reality of evolving virtual libraries in Nigeria. These indicators include the availability of information infrastructures, human capacity building programmes in ICT and the levels of funding of university libraries.

\subsection{Statement of the Problem}

The fundamental purpose of the library is to provide information services that are timely, useful and accessible to library patrons. With ICT, libraries are provided with options to providing electronic services. School Librarians (SL) and or School Library Media Specialist (SLMS) are professionals that can utilize information resources in digitized formats to offer quality and timely services to school library clienteles. Today's SL/SLMS provides students with access to a wide range of electronic information resources in developed nation. However, it is yet to be determined in a developing nation like Nigeria, if SL/SLMS are really familiar with such services, are they as professionals really making effective use of it? Do they (SL/SLMC) really have a kind of similar perception or do they differ in their views about this current technological services provided by libraries?

The above are some of the questions that were asked by this researcher. But it is remarkable to point out that few studies such as Abubakar (2012), Inyiama and Asogwa (2012), Ukpanah and Akpan (2012), have attempted to look at the evolution of digital libraries and their prospect and challenges. However, none of these writers conducted a research on perception and awareness of information professionals especially in relation to how they perceive this new technology in terms of awareness, importance, access and rating of digital resources and motivation to go digital. This is the main focus of this research.

\subsection{Objective of the Study}

The objectives of this research were as follows:-

1. To determine the SLMS awareness of digital library services

2. To determine SLMS perceptions about the digital library services

3. To find out how SLMS rate digital library resources and contents

4. To determine the SLMS readiness for digital service training

5. To determine the conditions that will motivate SLMS to go digital

\subsection{Research Questions}

This study is guided by the following questions:

1. Are the SLMS aware of digital library services?

2. How do the SLMS perceive digital library services? 
3. How do the SLMS rate digital library resources and content?

4. Are SLMS trained to function in digital information system?

5. What will motivate SLMS to go digital as professionals?

\subsection{Significance of Study}

The main objective of this research was to determine SLMS awareness and perceptions of the digital library services in Nigeria. It also investigated how they rate resources and content of the digital library collection. The study also identified the professional and educational training which is/ are required to function in a digital information system, this is to aid SLMS performance as digital librarians. It is very significant to also justify what will motivate SLMS in Nigeria to go digital. This research is also significant because digital library use today tends to affect both SLMS and students learning and performance and therefore can be considered as important tool in the school environment. Hence, it is expected to be useful for libraries, users and researchers. In addition, this research will contribute to the field of existing literature to greatly benefit the SLMS, students and researchers. Besides giving tremendous implications to library practice and training, this research is also expected to contribute to the field of school library media, digital library research concept and methodology. Most importantly, the library school will be able to ascertain the problems or barriers encountered by practicing librarians and SLMS in the use of the digital library collections and services. Therefore, the study would help libraries to improve on digital library collections and services and as well, plan for future digital library services to meet the changing needs of various types of library multi- dimensional professionals and students.

\section{METHODOLOGY}

The aim of this study was to survey librarians' awareness and perceptions of digital library services. Thus, quantitative survey method was adjudged as the best method for this type of research. A sample size of ninety professionally trained school librarians which were randomly selected among the one hundred and eight participants that attended the $26^{\text {th }}$ Annual conference and general meeting of the Nigerian School Library Association held at the Federal Polytechnic, Ado-Ekiti were selected for the study. The Critical Appraisal of Digital Library Awareness and Perception Questionnaires (CADLAPQ) which was an adapted questionnaire consisting of five parts: Demographics and digital Library Awareness/Perception background; rating of digital library resources; Digital content Recommendation; Professional Training/ Education of Librarians and Motivational requirements to go digital as professionals were personally administered and collected from respondents by the researcher. However, eighty six questionnaires (Approx. $96 \%$ ) only were returned while four $(4 \%)$ were unreturned. The data collected were analyzed using descriptive statistical tools such as tables, charts, graphs, percentages and frequency distribution.

\subsection{Data Analysis and Interpretation of Result}

Data collected were analyzed and the results presented as shown in Table 1
Table 1:Demographic Distribution of Respondents

\begin{tabular}{|c|c|c|c|}
\hline Variable & Description & Frequency & $\%$ \\
\hline \multirow[t]{3}{*}{ Gender } & Female & 46 & $53.5 \%$ \\
\hline & Male & 35 & $40.7 \%$ \\
\hline & Unspecified & 5 & $5.8 \%$ \\
\hline \multirow[t]{3}{*}{ Designation } & School Librarians & 68 & $67.4 \%$ \\
\hline & $\begin{array}{l}\text { Library Officer and Assistant Library } \\
\text { Officer/ Library assistants }\end{array}$ & 16 & $18.6 \%$ \\
\hline & Executive Officer & 2 & $2.3 \%$ \\
\hline \multirow[t]{6}{*}{ Affiliation(s) } & $\begin{array}{l}\text { Federal and State/ Private Secondary } \\
\text { Schools }\end{array}$ & 58 & $67.4 \%$ \\
\hline & Colleges of Education & 10 & $11.6 \%$ \\
\hline & LGEA/SUBEB & 5 & $5.8 \%$ \\
\hline & Library board/ Ministry of Education & 6 & $7.1 \%$ \\
\hline & Primary Schools/ Resources Centre & 5 & $5.8 \%$ \\
\hline & Academic Library & 2 & $2.3 \%$ \\
\hline \multirow[t]{2}{*}{ Certification } & Professional Librarian & 75 & $87.2 \%$ \\
\hline & Professional Teacher & 11 & $12.8 \%$ \\
\hline \multirow{3}{*}{$\begin{array}{l}\text { Educational } \\
\text { Qualification }\end{array}$} & Master in Library Studies (MLS), & 25 & $29.1 \%$ \\
\hline & $\begin{array}{l}\text { Bachelor in Library Studies (BLS), } \\
\text { Postgraduate Diploma in library science } \\
\text { (PGD), Bachelor of Art (Education) } \\
\text { (BA.(Ed), }\end{array}$ & 51 & $59.3 \%$ \\
\hline & $\begin{array}{l}\text { Higher National Diploma (HND), } \\
\text { Diploma, Nigerian Certificate in } \\
\text { Education (NCE), and General } \\
\text { Certification in Education (GCE } \\
\text { O/Level). }\end{array}$ & 10 & $11.6 \%$ \\
\hline
\end{tabular}

Table1.shows the demographic characteristics of the respondent. The results indicated that there were 46 (53.5\%) female, 35(40.6) male and $5(5.8 \%)$ did not specified their gender. This is not surprising because, it is general knowledge that librarianship is a female dominated profession. In terms of designation, majority of the respondents, $58(67.4 \%)$ were school Librarians from federal and state/ private secondary schools in Nigeria; 10 $(11.6 \%)$ were from colleges of Education; 5(5.8\%) from LGEA / SUBEB, only $6(7.1 \%)$ are from Library board/ the Ministry of Education, 5(5.8\%) are from primary schools /Resources Centers and only 2 (2.3\%) from Academic Library respectively. This is to say that, the school librarians are far much in number than the others.

Table 1 also shows that more than half $(1 / 2)$ of the respondents constituting $58(67.4 \%)$ were from the secondary school libraries, i.e. private federal and state. This is in line when compared with the total population of the respondents. This is followed by the certification with $75(87.2 \%)$ professional librarians as respondents, while 11 $(12.8 \%)$ are professional teachers. It was also observed that, the respondents have divergent Educational backgrounds; $25(29.1 \%)$ has Master in Library Studies (MLS), $51(59.3 \%)$ possess the Bachelor in Library Studies (BLS), Postgraduate Diploma in library science (PGD), Bachelor of Art (Education) (BA.(Ed) and only 10 $(11.6 \%)$ possess the Higher National Diploma (HND), Diploma, Nigerian Certificate in Education (NCE), and General Certification in Education (GCE O/Level). This indicated that majority of the respondents possess the MLS certification.

\subsection{Information on Digital Library Awareness and Perception}

The librarian, who is imbued with an ethics of equitable access, will function well as trained intermediaries in a heterogeneous information environment. The knowledge that a professional librarian bring to the knowledge environment would make sense of a multiplicity of collection and resources. In order to provide access to a network of key experience online and with others. The frequency distribution of participant's responses in respect to their perception of what a digital library services is, is shown in table 2 . 
Table 2: Frequency Distribution of Respondents Perception/awareness of Digital library Services

\begin{tabular}{|l|l|l|l|l|}
\hline $\begin{array}{l}\text { Digital } \\
\text { Library }\end{array}$ & Yes & $\%$ & No & $\%$ \\
\hline $\begin{array}{l}\text { Perception/ } \\
\text { awareness } \\
\text { Rating }\end{array}$ & 24 & $\begin{array}{l}27.9 \\
\%\end{array}$ & 62 & $\begin{array}{l}72.1 \\
\%\end{array}$ \\
\hline $\begin{array}{l}\text { Online } \\
\text { Catalogue }\end{array}$ & 66 & $\begin{array}{l}76.7 \\
\%\end{array}$ & 20 & $\begin{array}{l}23.3 \\
\%\end{array}$ \\
\hline $\begin{array}{l}\text { Library } \\
\text { software }\end{array}$ & 25 & $\begin{array}{l}29.1 \\
\%\end{array}$ & 61 & $\begin{array}{l}70.9 \\
\%\end{array}$ \\
\hline $\begin{array}{l}\text { Electronic } \\
\text { library/virt } \\
\text { ual library }\end{array}$ & 80 & $\begin{array}{l}93.0 \\
\%\end{array}$ & 6 & $7.0 \%$ \\
\hline Device & 12 & $\begin{array}{l}14.0 \\
\%\end{array}$ & 74 & $\begin{array}{l}86.0 \\
\%\end{array}$ \\
\hline $\begin{array}{l}\text { Online } \\
\text { Collections }\end{array}$ & 69 & $\begin{array}{l}80.2 \\
\%\end{array}$ & 17 & $\begin{array}{l}20.0 \\
\%\end{array}$ \\
\hline
\end{tabular}

From the analysis on Table 2:, 24 (27.9\%) of the respondents indicated that they are aware of the existence of digital library services, this depicted that majority 62 (72.1\%) are not aware of the existence of digital library services, while only 24 (27.9\%) indicated awareness.

On considerable degree of perception of what a digital library really is, $66(76.7 \%)$ perceived digital libraries as the Online Catalogue by ticking "yes" to confirm it as online catalogue and 20 (23.3\%) disagreed by ticking "no." Also, 25 respondents constituting $(29.1 \%)$ perceived it as library software, while the remaining 61 (70.9\%) disagreed. Perception as an electronic library/Virtual/automated/Computerize library indicated 80 (93\%) while the remaining $6(7.0 \%)$ do not perceive it so. At the same time, $12(14.0 \%)$ perceived it as devices, and majority $74(86.0 \%)$ said it is not while in addition, 69 $(80.2 \%)$ believed that digital library services are online collection and 17 (20\%) disagreed.

\subsection{Rating of Library Digital Resources}

This section describes the key digital resources needs and requirement concerning both the functionality of the digital libraries and other non-functional characteristics relating to interaction and importance of resources to digital libraries services, as shown in Table 3 :

Table 3: Frequency distribution regarding Rating of Library Digital Resources in Order of Importance

\begin{tabular}{|l|l|l|l|}
\hline $\begin{array}{l}\text { Digital } \\
\text { Library } \\
\text { Resources }\end{array}$ & EI & SI & NVI \\
\hline $\begin{array}{l}\text { Images/Vis } \\
\text { ual } \\
\text { Materials }\end{array}$ & $\begin{array}{l}45 \\
(52.3 \%)\end{array}$ & $\begin{array}{l}31 \\
(36.0 \%)\end{array}$ & $\begin{array}{l}10 \\
(12.0 \%)\end{array}$ \\
\hline $\begin{array}{l}\text { News/other } \\
\text { media } \\
\text { resources; }\end{array}$ & $\begin{array}{l}56 \\
(65.3 \%)\end{array}$ & $\begin{array}{l}25 \\
(29.0 \%)\end{array}$ & $\begin{array}{l}5 \\
(6.0 \%)\end{array}$ \\
\hline $\begin{array}{l}\text { Online } \\
\text { Reference } \\
\text { Resources }\end{array}$ & $\begin{array}{l}50 \\
(58.0 \%)\end{array}$ & $\begin{array}{l}28 \\
(32.5 \%)\end{array}$ & $\begin{array}{l}8 \\
(9.3 \%)\end{array}$ \\
\hline Databases; & 66 & 18 & 2 \\
\hline
\end{tabular}

\begin{tabular}{|c|c|c|c|}
\hline & $(76.7 \%)$ & $(20.9 \%)$ & $(2.3 \%)$ \\
\hline $\begin{array}{l}\text { Data } \\
\text { Archives, }\end{array}$ & $\begin{array}{l}74 \\
(86.0 \%) \\
\end{array}$ & $\begin{array}{l}10 \\
(11.6 \%)\end{array}$ & $\begin{array}{l}2 \\
(2.3 \%)\end{array}$ \\
\hline $\begin{array}{l}\text { Portals that } \\
\text { provides } \\
\text { links to } \\
\text { other URLs }\end{array}$ & $\begin{array}{l}12 \\
(13.9 \%)\end{array}$ & $\begin{array}{l}54 \\
(62.8 \%)\end{array}$ & $\begin{array}{l}20 \\
(23.3 \%)\end{array}$ \\
\hline $\begin{array}{l}\text { Digital } \\
\text { Films/Vide } \\
\text { o }\end{array}$ & $\begin{array}{l}10 \\
(11.6 \%)\end{array}$ & $\begin{array}{l}54 \\
(62.8 \%)\end{array}$ & $\begin{array}{l}22 \\
(25.6 \%)\end{array}$ \\
\hline $\begin{array}{l}\text { Audio } \\
\text { Materials, }\end{array}$ & $\begin{array}{l}30 \\
(34.8 \%)\end{array}$ & $\begin{array}{l}35 \\
(40.7 \%)\end{array}$ & $\begin{array}{l}21 \\
(24.4 \%)\end{array}$ \\
\hline $\begin{array}{l}\text { Stimulation } \\
\mathrm{s}\end{array}$ & $\begin{array}{l}24 \\
(27.9 \%)\end{array}$ & $\begin{array}{l}61 \\
(70.9 \%) \\
\end{array}$ & $\begin{array}{l}2 \\
(2.3 \%) \\
\end{array}$ \\
\hline Animation & $\begin{array}{l}60 \\
(69.8 \%)\end{array}$ & $\begin{array}{l}6 \\
(6.9 \%)\end{array}$ & $\begin{array}{l}20 \\
(23.3 \%)\end{array}$ \\
\hline
\end{tabular}

Key: $\mathbf{E I}=$ Extremely Important, $\mathrm{Sl}=$ Somewhat Important, NVl = Not Very Important

Various digital library resources were analyzed and categorized into extremely and not very important resources for digital libraries. Figure 1 is a bar chart showing the order in which the surveyed respondents' perceived these resources in order of importance. This section of the result gave an analysis of the rating order of importance of ten different digital resources only. Majority of the respondents rated Images/visual materials, News/other media resources; online reference resources, databases resources as extremely important while they rated Data Archives, Portals that provides links to other URLs relevant to particular disciplinary topic, Digital films/videos, audio materials as somewhat important:, while other such as stimulations/animation were rated as not very important as shown in figure 1.3:

From the analysis of data from Figure 1, Data Archives, Databases, Animations and News/other media resources were rated highly with $86 \%, 76 \%, 69 \%$ and $65 \%$ respondent considering them as extremely important. On the other hand simulation, Digital films/video and portals providing links to other URL's were rated as somewhat important, on $\%$ of 70,62 and 62 only. Other digital resources were considered by respondents as not very important with varying percentages.

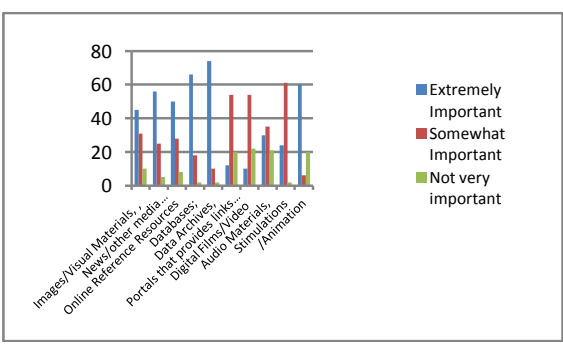

Figure 1: Rating of Digital Resources in Other of Importance

\subsection{Content of the Digital Library Services}

The various content of a digital library as recommended by respondents were analyzed and categorize into great extent and not at all categories of responses. With virtual library resources, online textbooks, postcards/video and skill 
development software, games and animation/stimulation recommended on a scale of a very great extent by all the $86 \%$ respondents, $(100 \%)$ while real time data was recommended and rated only to an extent by $55(78 \%)$, others $15(21.4 \%)$ were undecided in their rating. Table 4 shows the state of affair for the digital library content rating.

Table 4: Rating of Digital Library Service

\begin{tabular}{|l|l|l|l|l|}
\hline Content & VGE & \% & E & \% \\
\hline $\begin{array}{l}\text { Virtual } \\
\text { Library } \\
\text { Resources }\end{array}$ & 86 & 100 & - & - \\
\hline $\begin{array}{l}\text { Online } \\
\text { Textbooks (e- } \\
\text { Books) }\end{array}$ & 86 & 100 & - & - \\
\hline $\begin{array}{l}\text { Postcards/vide } \\
\text { o }\end{array}$ & 86 & 100 & - & - \\
\hline $\begin{array}{l}\text { Skill } \\
\text { Development } \\
\text { Software }\end{array}$ & 86 & 100 & - & - \\
\hline Games & 86 & 100 & - & - \\
\hline $\begin{array}{l}\text { Animation/sti } \\
\text { mulation }\end{array}$ & - & - & 55 & 63.9 \\
\hline Real time data & - & - & 31 & 36.0 \\
\hline
\end{tabular}

Key: VGE= Very great Extent $; \mathrm{E}=$ An Extent

Table 4 shows that all of the respondents 86 $(100 \%)$, perceived that the content of a digital library should be made up of virtual library resources, online textbooks, postcards/video and skill development software, games and animation/stimulation, hence they perceived and recommended them on a scale of a very great extent. By enquiry from some of the respondent whether such content are helpful, all $(100 \%)$ of them agreed that these digital contents will be helpful to their student. Based on the above analysis, a digital Library that contains the above contents is considered and adjudged to be satisfactory for academic use, although the content may not be restricted to these alone.

\subsection{Professional Training/Education on Digital Information Systems}

The frequency distribution of participants responses to some of the professional training require to function in digital information system is shown in Table 5. In order to aid performances as digital librarians, some of the trainings which were considered important by respondents include computerized text analysis, database creation and distribution, design of interphase and retrieval language document; Virtual reality, communication formats, data resources/management and data mining/knowledge respectively. Thus, from the result all the respondents $(100 \%)$ indicated by ticking "No" to state that they do not have any of the professional training or education on digital information system. It is therefore very clear that all the participation do not have professional trainings which are necessary for librarians to function in digital information system.

Table 5: Frequency Distribution of Participants Professional Training in Digital Information System

\begin{tabular}{|l|l|l|l|l|}
\hline Professional Training & Yes & \% & No & \% \\
\hline $\begin{array}{l}\text { Computerized Text } \\
\text { Analysis }\end{array}$ & - & - & 86 & $\mathbf{1 0 0 \%}$ \\
\hline $\begin{array}{l}\text { Database Creation and } \\
\text { Distribution }\end{array}$ & - & - & 86 & $\mathbf{1 0 0 \%}$ \\
\hline $\begin{array}{l}\text { Design of Interphase and } \\
\text { Retrieval Language } \\
\text { Document }\end{array}$ & - & - & 86 & $\mathbf{1 0 0 \%}$ \\
\hline Virtual Reality & - & - & 86 & $\mathbf{1 0 0 \%}$ \\
\hline $\begin{array}{l}\text { Data } \\
\text { Resources/Management }\end{array}$ & - & - & 86 & $\mathbf{1 0 0 \%}$ \\
\hline Communication Formats & - & - & 86 & $\mathbf{1 0 0 \%}$ \\
\hline
\end{tabular}

\subsection{Motivation to go Digital}

In other to show the rate of motivation to go digital if giving the opportunity, Yes or No ratings were allocated to elicit responses on what will motivate respondents to go digital as professionals. Thus, Table 6 depicts the result of respondents to what will motivate them as professional to go digital.

Table 6: Table of Motivation to Go Digital

\begin{tabular}{|l|l|l|}
\hline Motivational Factor & $\begin{array}{l}\text { No of } \\
\text { Respondents }\end{array}$ & $\begin{array}{l}\text { \% } \\
\text { respondents }\end{array}$ \\
\hline $\begin{array}{l}\text { Work Condition } \\
\text { Flexibility }\end{array}$ & 10 & $\mathbf{1 1 . 6 \%}$ \\
\hline Increase Compensation & 12 & $\mathbf{1 4 \%}$ \\
\hline $\begin{array}{l}\text { Provision of } \\
\text { Technology }\end{array}$ & 25 & $\mathbf{2 9 \%}$ \\
\hline In-Service Training & 26 & $\mathbf{3 0 \%}$ \\
\hline $\begin{array}{l}\text { Workshop./ } \\
\text { Conferences Experience }\end{array}$ & 11 & $\mathbf{1 3 \%}$ \\
\hline $\begin{array}{l}\text { Work } \\
\text { Online }\end{array}$ & $\mathbf{3 \%}$ \\
\hline
\end{tabular}

From the result analysis as revealed in Table 6, factors which will be able to motivate respondents to go digital include work condition flexibility, increase compensation, provision of technology, training, work. From the table Inservice training recorded the highest percentage of $30 \%$ from 26 respondents; followed by provision of technology, which recorded $29 \%$ from 25 respondents. Other factors of increase compensation, workshop/conference and work condition flexibility recorded $14 \%, 13 \%$ and $11.6 \%$ respectively as motivation to go digital. While work experience online recorded 3\% from only 3 respondents.

\section{Figure 2: Table of Motivation to}

Go Digital

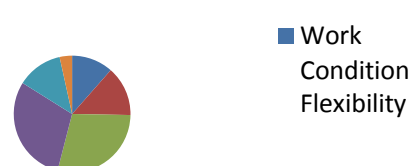

Figure 2 is a pie-chart representation of what will motivate Nigeria SLMSs to go digital as professionals in order of percentages as revealed from Table 6.

Figure 2 shows the response rate as regards the motivation to go digital. It indicated that majority of respondents constituting $30 \%$ and $25 \%$ respectively believed that inservices training and the provision of technology will motivate them as professionals to go digital. This responses are closely followed by that of the $14 \%$ and $13 \%$ 
respondents who believed that increase in compensation and attendance at professional conferences and workshop will motivate them to go digital. While, work condition flexibility recorded $10(11 \%)$ and work experience online recorded $3(3 \%)$ only as reasons that could move the respondents to go digital.

\section{CONCLUSION}

This study is basically concern with examining the SLMS awareness of digital library services, how SLMS/SLS perceive digital library services and what is their awareness about the resources and contents of it. The study also examine the readiness of SLMS and the conditions that will motivate them as professional to "go digital". Collected data were analyzed and some existing shortcomings on the side of the training received by SLMS/SLs was revealed. Therefore, this questionnairebased survey has evolved a variety of issues which are considered to be pertinent to the survey of this awareness and perception of Digital Libraries Service among SLMS/SLs in Nigeria. The result of this research have revealed and established that SLMS/School Librarians in Nigeria exhibit a variety of characteristics concerning gender, designation, educational level, digital awareness background and varied perception of DLS. Nevertheless most respondents have a recurrent perception pattern of DLS as online catalogue, library software etc.

In particular, it has emerged that SLMS/School Librarians as professionals and stakeholders of library services have different views and conceptualization of DLS systems and their uses. Thus, from the analyzed data of the survey, it is evident that the traditional "school librarian in Nigerian schools still perceive in a prevailing DL world that the DL is the OPAC, based on their low degrees of awareness of what a Digital libraries really is. As professional, SLMS/SLs must knowledgeable. Awareness need to be created for them to know what digital libraries and their services are all about, they should be made to know also, the fact that the Digital library services can enable students to leverage information, by bridging the gap between the context of information and the application of knowledge and that technology should be taken as a catalyst, rather than as the problem.

On the Digital library resources and content, appropriate education about the different resources and facilities of a DL is necessary to help improve/change the perception of SL, It is natural that, SLMS/SLs be made aware of the resources and contents of a DL. As professional and expert, professional training to function in the Digital Information System is necessary. Their training could include data mining, data resources and retrieval language analysis among other training required to function in a Digital Information Systems. Additionally, as professional they do not appear to have a clear understanding of the possible advantages of DLS. The above may be an explanation for the different levels of awareness, among respondents. In addition, this survey have been able to highlight the need to provide professional motivation to undergo digital service training by SLMS/SLs. This will require a very careful consideration by all stakeholders of education to further bridge the digital divide in a developing nation like Nigeria. Hence, in order to develop and deploy effective digital library service in Nigeria, the educational needs of the SLMS/SL are germane to a digital library creation effort. For their readiness for digital services training and the motivation to go digital, the provision of technology, training, work experience online with teacher librarian and work condition flexibility is $a$ sine qua non

\section{RECOMMENDATIONS}

Overall, the SLMS/SLs need to be educated and reoriented to pay attention to the existence of Digital Library Services. Generally, as observed, there is the need to embarked on the training and re-training among the community of SLMS/SLs to create awareness and to realign their view with that of the outside world.

\section{ACKNOWLEDGEMENT}

The Author acknowledge with thanks all the researchers, whose work was consulted to put this paper together. Special thanks go to my Head of Department Dr. Oyewusi Folakemi of the Center for Educational Media Resources (CERMS), University of Ibadan , Ibadan, Nigeria for giving me the opportunity to present a paper titles Digital Library: Myth and Reality at the Nigeria School Library Association Annual AGM/ National Conference held in Ado Ekiti. The shocking responses and questions asked by participants during the conference gave birth to this research. I Also appreciated my lecturers from CEMRS, Dr. Aramide Kolawole, Dr. Olaojo Pius and my Supervisor, a father and a Mentor who taught me how to do research, Professor Adams O. Onuka of the Institute of Education, University of Ibadan. Thank you sir for supervising my $\mathrm{PhD}$ thesis

\section{REFERENCES}

[1] Association of Research Libraries (1995) definition and purposes of a digital library. http://www.arl.org/html(October 7, 2013)

[2] Onuka, A. \& Towolawi, K. O. (2012) Networking Higher Educational Research for Effective Teaching in a Developing Country In International Centre for Mathematical \& Computer Sciences, Lagos, Nigeria ICMCS: 5, Pages 51-65

[3] Bagudu, A. A \& Sadiq, H 2013 Students' Perception of Digital Library Services: a case Study of International Islamic University, Malaysia. Library Philosophy and Practice [Online] http://digitalcommons.unl.edu/libphilprac/894

[4] Borgman, Christine L., Gilliland-Swetland, Anne. G, Leazer, Gregory H, Mayer, Richard, Gwynn David, Gazan Rich \& Mautone Patricia (2000) Evaluating Digital Libraries for Teaching and Learning in Undergraduate Education: A Case Study of the Alexandria Digital Earth ProtoType Library Trends, 49, (2), 228-250

[5] Borgman, C. L \& Larsen, R. (2003) ECDL 2003 Workshop report: Digital library evaluation metrics, test beds and processes. D-Lib Magazine 9(9) 51-59

[6] Borgman, C. L. (1999) what are digital libraries? Competing visions. Information Processing and Management 35, 227-243.

[7] Kimani, E., Panizzi, T. \& Catarci, M. A., (2005) Digital Library Requirements: a Questionnaire-based Study

[Online] 
available:http://citeseerx.ist.psu.edu/viewdoc/downloa d?doi=10.1.1.98.7401 ( July 20, 2015)

[8] John, W. Berry, (1996) "Digital libraries: new initiatives with worldwide implications", Collection Building, 15 (4), 21 - 33

[9] Ubogu, F. N., (2006) Trends in Digital Library Services in Academic Libraries in South Africa: Library Portals and ETD system being a paper presented at the $44^{\text {th }}$ National conference and AGM of the Nigeria Library Association held from 18-23, June , 2006 at Abuja. Nigeria .

[10] Fuhr, Nobert., et.al (2007) Evaluation of digital libraries International Journal of Digital Library 8, 21-38

[11] Fuhr, N., Tsakonas, G., Aalberg, T., Agosti, M., Hansen, P., \& Kapidakis, S. (2007). Evaluation of digital libraries. International Journal on Digital Libraries, 8(1), 21-38.

[12] Xie, H. I. (2007). User evaluation of digital libraries: their uses, their criteria and their assessment. Information Processing and Management, 44, 13461373

[13] Abubakar, B. Magaji., (2010) Digital Libraries in Nigeria in the Era of Global Change: A Perspective of the Major Challenges. TRIM 6 (2) 22-36

[14] Inyiama, H.C \& Asogwa, C. N., (2011) Evolution of Digital Libraries in Nigeria: Problems and Prospects The IUP Journal of Information Technology, 7(4) 1830

[15] John W. Berry, (1996) "Digital libraries: new initiatives with worldwide implications", Collection Building 15(4), 21 - 33

[16] Adams, Anne \& Blandford, Ann (2002) The unseen and unacceptable face of digital libraries.
International Journal of Digital Libraries, 4(2), 7181.

[17] Kanyengo, C. W., (2006) Managing Digital Information Resources in Africa: preserving the integrity of scholarship being a Paper Presented at the Bridging the North-South Divide in Scholarly Communication on Africa: threats and Opportunities in the Digital era. Held at Leiden, the Netherlands, 68 September 2006

[18] Bodomo Adams, Lam Mei-ling \& Lee Carmen (2003) some students still read books in the 21 st century: a study of User preferences for print and electronic libraries The Reading Matrix 3(3) 20-43

[19] Ubogu, Felix N. (2006) Trends in Digital Library Services in Academic Libraries in South Africa: Library Portals and ETD System Libraries: Papers Presented At the 44th Annual Conference and Annual General Meeting of the Nigerian Library Association, 2006 themed Libraries as dynamic engines for the Knowledge and information society

[20] Speirs, Martha (2006) Resource Sharing In the Digital Age, ABTI-American University, Yola Papers Presented At the 44th Annual Conference and Annual General Meeting of the Nigerian Library Association, 2006

[21] Daniel, Greenstein., \& Suzanne, E. T., (2003) The Digital Library: A Biography [Online]http://isnet.hbi.ir/web/files/elib/pages/docs/ar ticle/biography.pdf (August 16th, 2014)

[22] Omekwu, C. Obiora., (2006) "Managing information and technology: critical roles for librarians in developing countries", Electronic Library, 24 (6), $.847-863$

[23] Ukpanah, M. Etukudo \& Akpan, U. John (2012) Innovations in Nigerian libraries in the 21st century Journal of Resourcefulness and Distinction, 2 (1) 12 28. 